\title{
Tingkat Kejadian Gangguan Reproduksi Sapi Bali dan Madura pada Sistem Pemeliharaan Kandang Kelompok
}

\author{
(The Incidence of Reproductive Disorders in Bali and Madura Cattle on \\ Maintained Housing Groups System)
}

\author{
Luthfi M, Widyaningrum Y \\ Loka Penelitian Sapi Potong, Jl. Pahlawan No. 2, Grati, Pasuruan, Jawa Timur \\ luthfi.m888@gmail.com
}

\begin{abstract}
This study aims to provide information on cases of reproductive disorders in beef cattle which maintenance systems group in the Beef Cattle Research Station of the year 2013-2016. The material used was 130 Bali and Madura cattle. The parameters observed dystocia, abortion, retained scundinae, uterine prolapse. Data were analyzed descriptively. The results showed reproductive disorders in Bali cows 2 years old dystocia highest cases $(3.08 \%)$ and abortion $(0.77 \%)$, at the age of 5 years in case of the highest retention $(4.62 \%)$, then in the Madura cows at age 3 cases of uterine prolapse and retained scundinae each (1.54\%), the age of 4 years in case of the highest retention scundinae $(2.31 \%)$, aged 5 years scundinae retained the highest cases $(3.86 \%)$. The incidence of reproductive disorders in Bali cows body weight poor level $(\leq 250 \mathrm{~kg})$ cases that present the highest retention scundinae $(3.08 \%)$, body weights moderate level $(251-300 \mathrm{~kg}$ ), dystocia $(0.77 \%)$ and retention scundinae $(0.77 \%)$, the body weight fat level $(\geq 301 \mathrm{~kg})$ retained scundinae cases $(0.77 \%)$; Madura cows body weight poor level scundinae retained the highest cases $(3.08 \%)$, the weight being retained scundinae cases $(1.54 \%)$ and body weighted fat level retention scundinae cases $(0.77 \%)$. Reproductive disorders in Bali cows low birth weight $(\leq 15 \mathrm{~kg})$ retained the highest case scundinae $(4.62 \%)$, moderate birth weight $(16-20 \mathrm{~kg})$ and height dystocia cases arising each (1.54\%); for Madura cows at a lower weight retention scundinae highest cases $(3.08 \%)$, medium and high weight retention scundinae each $(2.31 \%)$. The conclusion is that the highest incidence rates in reproductive disorders based on age, weight of the cows birth and birth weight in Bali and Madura cows is retained scundinae case. Therefore, prevention can be done by paying attention to the feed, houses, sanitation, health and cows because reproduction capabilities of each cows is different.
\end{abstract}

Key Words: Reproductive Disorders, Bali Cattle, Madura Cattle, Housing Groups

\begin{abstract}
ABSTRAK
Penelitian ini bertujuan memberikan informasi kasus-kasus gangguan reproduksi pada sapi potong induk dengan sistem pemeliharaan kandang kelompok di Kandang Percobaan Loka Penelitian Sapi potong dari tahun 2013-2016. Materi yang digunakan induk sapi Bali dan induk sapi Madura masing-masing 130 ekor. Parameter yang diamati distokia, abortus, retensio scundinae, prolapsus uteri. Data dianalisis secara deskriptif. Hasil pengamatan menunjukkan gangguan reproduksi pada induk sapi Bali umur dua tahun kasus tertinggi distokia $(3,08 \%)$ dan abortus $(0,77 \%)$, umur 5 tahun terjadi kasus tertinggi retensio scundinae $(4,62 \%)$, selanjutnya pada induk sapi Madura umur 3 tahun kasus prolapsus uteri dan retensio scundinae masing-masing $(1,54 \%)$, pada umur 4 tahun terjadi kasus tertinggi retensio scundinae $(2,31 \%)$, dan pada umur 5 tahun kasus tertinggi retensio scundinae $(3,86 \%)$. Kejadian gangguan reproduksi induk sapi Bali bobot ringan $(\leq 250 \mathrm{~kg})$ kasus yang muncul tertinggi retensio scundinae $(3,08 \%)$, pada induk bobot sedang $(251-300 \mathrm{~kg})$ distokia $(0,77 \%)$ dan retensi scundinae $(0,77 \%)$, pada induk bobot gemuk $(\geq 301 \mathrm{~kg})$ kasus retensio scundinae $(0,77 \%)$. Sedangkan pada induk sapi Madura bobot ringan kasus tertinggi retensio scundinae $(3,08 \%)$, pada yang bobot sedang kasus retensio scundinae $(1,54 \%)$ dan pada yang bobot gemuk kasus retensio scundinae $(0,77 \%)$. Gangguan reproduksi
\end{abstract}


induk sapi Bali yang bobot lahir rendah $(\leq 15 \mathrm{~kg})$ kasus tertinggi retensio scundinae $(4,62 \%)$, bobot lahir sedang (16-20 kg) dan pada sapi dengan bobot lahir tinggi kasus yang muncul distokia masing-masing $(1,54 \%)$. Untuk induk sapi Madura yang bobot rendah kasus tertinggi retensio scundinae $(3,08 \%)$, pada bobot sedang dan tinggi retensio scundinae masing-masing $(2,31 \%)$. Disimpulkan bahwa tingkat kejadian tertinggi pada gangguan reproduksi berdasarkan umur, bobot induk waktu melahirkan dan bobot lahir pada sapi Bali dan Madura adalah kasus retensio scundinae. Oleh karena itu pencegahan dapat dilakukan dengan memperhatikan pakan, kandang, sanitasi, kesehatan dan bangsa sapi karena kemampuan reproduksi masing-masing bangsa sapi berbeda.

Kata Kunci: Gangguan Reproduksi, Sapi Bali, Sapi Madura, Kandang Kelompok

\section{PENDAHULUAN}

Indonesia memiliki kekayaan sumberdaya genetik lokal (plasma nutfah) yang perlu dimanfaatkan secara optimal. Sapi Bali dan Madura merupakan sumberdaya genetik ternak asli Indonesia, keberadaan kedua sapi tersebut harus dijaga baik populasi maupun kemurnian genetiknya (Nijman et al. 2003). Sapi ini memiliki keunggulan yaitu mudah beradaptasi dengan lingkungan di mana dia berada, walaupun dengan tatalaksana pemeliharaan sederhana, tidak selektif dalam memilih pakan dan mampu memberikan respon pertumbuhan yang baik bila diberi pakan dengan kualitas rendah. Di samping itu sapi Bali juga memiliki kelebihan tingkat kesuburannya tinggi (80-82\%), efek heterosis tinggi di persilangan (Noor et al. 2010) dan memiliki kualitas daging tinggi dan persentase yang rendah lemak (Bugiwati 2007).

Usaha peternakan di Indonesia hingga saat ini masih mengalami banyak kendala, yaitu produktivitas ternak masih rendah. Salah satu diantaranya adalah masih banyaknya gangguan reproduksi menuju kemajiran pada ternak betina, hal ini berakibat pada efisiensi reproduksi dan lambatnya perkembangan populasi ternak. Dengan demikian perlu adanya pengelolaan ternak yang baik agar daya tahan reproduksi meningkat sehingga menghasilkan efisiensi reproduksi tinggi yang diikuti dengan produktivitas ternak yang tinggi pula (Hayati \& Choliq 2009).

Target usaha pembibitan sapi potong adalah terjadinya kebuntingan hingga kelahiran setiap tahun, akan tetapi ada banyak hal yang menyebabkan terjadinya kegagalan kelahiran salah satunya adalah gangguan reproduksi. Kasus kejadian gangguan reproduksi memiliki dua implikasi selain kegagalan untuk mendapatkan pedet juga kematian induk akibat proses penanganan kelahiran yang tidak tepat.

Keberhasilan tingkat kebuntingan saja tidak cukup tapi harus sukses hingga terjadi kelahiran. Gangguan reproduksi yang menyebabkan kegagalan kelahiran memberikan kontribusi cukup besar pada peternak dalam memproduksi pedet, karena pedet yang telah dinanti selama \pm 285 hari akan mengalami kematian yang selanjutnya berakibat tertundanya proses pembibitan, jarak beranak semakin panjang, peningkatan biaya pakan dan tenaga kerja (Phocas \& Laloe 2003). Beberapa kejadian gangguan reproduksi yang sering terjadi di lapangan antara lain distokia, prolapsus uteri, retensio scundinae dan abortus. Oleh karena itu dalam penelitian ini dilakukan pengamatan tingkat kejadian gangguan reproduksi didasarkan pada umur induk, bobot badan induk dan bobot lahir pedet.

Tujuan penelitian ini adalah untuk memberikan informasi beberapa faktor yang harus diwaspadai agar kejadian kegagalan kelahiran akibat gangguan reproduksi dapat diminimalkan dalam usaha peternakan sapi potong. 


\section{MATERI DAN METODE}

\section{Materi}

Materi yang dipergunakan adalah data hasil recording sapi Bali dan Madura dari tahun 2013-2016 sebanyak 130 ekor induk sapi Bali dan 130 ekor induk sapi Madura pada kandang percobaan di Loka Penelitian Sapi Potong.

\section{Manajemen perkawinan}

Sistem perkawinan alam menggunakan pejantan unggul pada kandang kelompok dengan rasio pejantan dan induk yaitu 1:20 ekor. Ternak dikumpulkan di kandang kawin selama 3 bulan, dengan kepadatan 3-4 $\mathrm{m}^{2} /$ ekor. Berdasarkan hasil pemeriksaan kebuntingan (PKB), sapi yang bunting 3 bulan dimasukkan ke kandang bunting hingga umur kebuntingannya 9 bulan, sedangkan sapi yang tidak bunting tetap di kandang kawin. Induk yang umur kebuntingannya 9 bulan dipindahkan ke kandang beranak hingga terjadi proses kelahiran. Selanjutnya induk setelah 40 hari beranak dimasukan ke kandang kawin untuk segera dapat bunting lagi.

\section{Pemberian pakan}

Pakan yang diberikan mengacu pada pola Low External Input Sustainable Agriculture (LEISA) yaitu dengan memanfaatkan bahan - bahan limbah pertanian yang tersedia (dedak padi, tumpi jagung, kulit kopi dan jerami padi kering) serta rumput gajah dan disesuaikan dengan musim serta kecukupan kebutuhan pakan yang berdasar bahan kering (BK) ransum sebanyak 2-3\% bobot badan. Pakan diberikan 2 kali sehari yaitu pada pagi dan sore hari.

\section{Koleksi data}

Data dihimpun dari setiap kejadian kelahiran sapi, dicatat tanggal kelahiran, bobot induk saat melahirkan dan bobot pedet pada saat lahir. Kejadian gangguan reproduksi yang diamati yaitu distokia, prolapsus uteri, retensio scundinae dan abortus. Data yang diperoleh dianalisa secara diskriptif.

\section{Istilah gangguan reproduksi yang diamati}

Parameter yang diamati

- Kejadian distokia, prolapsus uteri, retensio scundinae dan abortus

- Distokia adalah suatu gangguan dari suatu proses kelahiran atau partus, yang dalam stadium pertama kelahiran (dilatasi cervix) dan kedua (pengeluaran fetus) lebih lama dan menjadi sulit dan tidak mungkin lagi bagi induk untuk mengeluarkan fetus kecuali dengan pertolongan manusia (Affandhy et al. 2007).

- Prolapsus uteri adalah pembalikan uterus, vagina dan cervix, menggantung keluar melalui vulva (Affandhy et al. 2007).

- Retensio scundinae adalah kejadian patologi dimana selaput fetus tidak keluar dari alat kelamin induknya dalam waktu 1-12 jam setelah kelahiran anaknya (Hardjopranjoto 1995).

- Abortus adalah pengeluaran fetus mati ataupun hidup pada setiap stadium kebuntingan sebelum waktunya kelahiran normal (Peters \& Ball 2007). 


\section{HASIL DAN PEMBAHASAN}

\section{Tingkat kejadian gangguan reproduksi}

\section{Berdasarkan umur induk}

Semakin cepat ternak dikawinkan maka semakin cepat pula ternak dapat berproduksi sehingga usaha peternakan semakin efisien dan ekonomis. Hasil penelitian menunjukkan bahwa terdapat empat kasus gangguan reproduksi yang terjadi pada sapi Bali dan sapi Madura berdasarkan umur induk disajikan pada Tabel 1.

Tabel 1. Persentase kejadian gangguan reproduksi berdasarkan umur induk waktu melahirkan

\begin{tabular}{|c|c|c|c|c|c|c|c|c|}
\hline \multirow{2}{*}{$\begin{array}{l}\text { Umur } \\
\text { induk }\end{array}$} & \multicolumn{4}{|c|}{$\begin{array}{l}\text { Sapi Bali } \\
\text { (130 ekor) }\end{array}$} & \multicolumn{4}{|c|}{$\begin{array}{l}\text { Sapi Madura } \\
\text { (130 ekor) }\end{array}$} \\
\hline & $\begin{array}{l}\text { Distokia } \\
(\%)\end{array}$ & $\begin{array}{c}\text { Prolapsus } \\
\text { uteri (\%) }\end{array}$ & $\begin{array}{l}\text { Retensio } \\
\text { scundinae } \\
(\%)\end{array}$ & $\begin{array}{l}\text { Abortus } \\
(\%)\end{array}$ & Distokia (\%) & $\begin{array}{c}\text { Prolapsus } \\
\text { uteri }(\%)\end{array}$ & $\begin{array}{c}\text { Retensio } \\
\text { scundinae } \\
(\%)\end{array}$ & $\begin{array}{c}\text { Abortus } \\
(\%)\end{array}$ \\
\hline 2 thn & 3,08 & 0,00 & 0,00 & 0,77 & 0,00 & 0,00 & 0,00 & 0,00 \\
\hline 3 thn & 0,00 & 0,00 & 0,00 & 0,00 & 0,00 & 1,54 & 1,54 & 0,00 \\
\hline 4 thn & 0,00 & 0,00 & 0,00 & 0,00 & 0,00 & 0,00 & 2,31 & 0,77 \\
\hline 5 thn & 0,00 & 0,77 & 4,62 & 0,00 & 0,00 & 0,77 & 3,85 & 0,00 \\
\hline Total & 3,08 & 0,77 & 4,62 & 0,77 & 0,00 & 2,31 & 7,69 & 0,77 \\
\hline
\end{tabular}

Berdasarkan hasil pengamatan pada Tabel 1. menunjukkan bahwa persentase kejadian gangguan reproduksi pada sapi Madura dimulai pada umur induk tiga tahun (kelahiran kedua) yaitu pada kasus prolapsus uteri dan retensio scundinae. Sedangkan pada sapi Bali persentase gangguan reproduksinya dimulai pada umur dua tahun (kelahiran pertama) yang meliputi kasus distokia selanjutnya pada umur lima tahun terdapat kasus prolapsus uteri dan retensio scundinae. Hasil ini senada dengan penelitian Anderson (2012) yang menyatakan bahwa persentase gangguan repoduksi tertinggi (distokia) terjadi pada induk umur dua tahun (kelahiran pertama) karena pada saat itu ukuran pinggul induk kecil sehingga pedet kesulitan untuk dikeluarkan. Terjadinya gangguan reproduksi pada induk umur muda kemungkinan dikarenakan kontrol manajemen pakan yang kurang baik sehingga sapi-sapi yang bunting terutama pada semester ketiga (menjelang kelahiran) mengalami kekurangan nutrisi. Lebih lanjut Salisbury \& Van Demark (1993) menyatakan bahwa umur dan bobot badan sapi dara pada waktu dikawinkan pertama kali perlu diperhatikan sebagai pertimbangan kelancaran proses beranak guna mencegah kejadian distokia.

Prolapsus uteri memiliki dampak finansial terhadap peternak dan pada kehidupan hewan yang mengalami gangguan reproduksi tersebut. Penanganan pada kasus sapi yang mengalami prolapsus uteri harus dilakukan dengan jalan operasi yang membutuhkan biaya cukup tinggi. Prolapsus uteri juga akan membuat harga jual sapi menjadi turun yang akan merugikan peternak.

Meskipun persentase kejadian abortus pada penelitian ini sangat rendah namun tetap harus diwaspadai karena secara ekonomis abortus adalah masalah besar bagi peternak akibat kehilangan foetus yang terkadang diikuti dengan penyakit pada uterus dan sterilitas yang lama. Menurut Toelihere (2006), bahwa agen penyebab abortus diklasifikasikan dalam beberapa kelompok yaitu sebab fisik, genetik, nutrisional, kimia obat, keracunan, 
hormonal, dan penyakit. Sedangkan penyakit umumnya disebabkan oleh bakteri, virus, jamur dan protozoa.

\section{Berdasarkan bobot badan induk}

Pada dasarnya retensio scundinae adalah kegagalan pelepasan villi kotiledon fetus dari kripta kurunkula maternal. Sesudah fetus keluar dan korda umbilikalis putus, tidak ada darah yang mengalir ke villi kotiledon fetus yang berakibat villi tersebut berkerut dan mengendur. Karena gangguan pelepasan villi fetus dari kripta maternal, maka akan terjadi pertautan (Toelihere 1985). Kejadian gangguan reproduksi berdasarkan bobot badan dapat dilihat pada Tabel 2.

Tabel 2. Persentase kejadian gangguan reproduksi berdasarkan bobot badan induk waktu melahirkan

\begin{tabular}{|c|c|c|c|c|c|c|c|c|}
\hline \multirow[b]{2}{*}{$\begin{array}{l}\text { Bobot } \\
\text { badan } \\
(\mathrm{kg})\end{array}$} & \multicolumn{4}{|c|}{ Sapi Bali (130 ekor) } & \multicolumn{4}{|c|}{ Sapi Madura (130 ekor) } \\
\hline & $\begin{array}{c}\text { Distokia } \\
(\%)\end{array}$ & $\begin{array}{c}\text { Prolapsus } \\
\text { uteri }(\%)\end{array}$ & $\begin{array}{l}\text { Retensio } \\
\text { scundinae } \\
(\%)\end{array}$ & $\begin{array}{l}\text { Abortus } \\
(\%)\end{array}$ & $\begin{array}{l}\text { Distokia } \\
(\%)\end{array}$ & $\begin{array}{c}\text { Prolapsus } \\
\text { uteri }(\%)\end{array}$ & $\begin{array}{l}\text { Retensio } \\
\text { scundinae } \\
(\%)\end{array}$ & $\begin{array}{c}\text { Abortus } \\
(\%)\end{array}$ \\
\hline $\begin{array}{l}\text { Ringan } \\
(\leq 250)\end{array}$ & 2,31 & 0,77 & 3,08 & 0,77 & 0,00 & 0,77 & 4,62 & 0,77 \\
\hline $\begin{array}{l}\text { Sedang } \\
(251- \\
300)\end{array}$ & 0,77 & 0,00 & 0,77 & 0,00 & 0,00 & 0,00 & 1,54 & 0,00 \\
\hline $\begin{array}{l}\text { Gemuk } \\
(\geq 301)\end{array}$ & 0,00 & 0,00 & 0,77 & 0,00 & 0,00 & 0,00 & 0,77 & 0,00 \\
\hline Total & 3,08 & 0,77 & 4,62 & 0,77 & 0,00 & 0,77 & 6,93 & 0,77 \\
\hline
\end{tabular}

Hasil pengamatan persentase kejadian gangguan reproduksi berdasarkan bobot badan induk saat melahirkan pada Tabel 2 menunjukkan bahwa pada bobot badan induk baik sapi Bali maupun Madura dengan katagori ringan persentase tingkat kejadian gangguan reproduksinya lebih banyak terutama kasus retensio scundinae selanjutnya untuk sapi Bali kasus distokia, prolapsus dan abortus. Hardjopranjoto (1995) melaporkan bahwa diagnosa retensio scundinae dapat dilakukan berdasarkan adanya plasenta yang keluar dari alat kelamin. Kejadian retensio scundinae didiagnosa melalui pemeriksaan per vaginal dalam waktu 24-36 jam post partus. Apabila pemeriksaan dilakukan lebih dari 48 jam akan mengalami kesulitan karena serviks sudah mulai menutup (Toelihere 1985). Begitu pula dengan kejadian abortus yang terjadi sebelum bulan ke lima masa kebuntingan jarang disertai dengan retensio scundinae, tetapi abortus yang terjadi setelah bulan ke empat masa kebuntingan, sering kali diikuti dengan adanya retensio scundinae (Roberts 2012).

Penggunaan limbah pertanian yang memiliki nilai serat kasar yang tinggi dalam pakan kemungkinan memicu munculnya kejadian gangguan reproduksi sapi Bali dan Madura pada penelitian ini. Menurut Anggorodi (1994) menyatakan bahwa, faktor pakan memainkan peranan penting dalam berbagai peristiwa faali yang terjadi dalam kelangsungan proses reproduksi. Defisiensi unsur pakan tertentu dapat menimbulkan kerusakan dan kegagalan total dalam proses reproduksi. Selanjutya menurut Tillman et al., (1998) fungsi reproduksi pada ternak tergantung pada beberapa perkembangan fisiologis alat-alat tubuh umumnya nyata dan saling berkaitan antara satu sama lain terutama organ reproduksi. Hambatan perkembangan tubuh tersebut akan menyebabkan sterilitas temporer atau permanen. 


\section{Berdasarkan bobot lahir pedet}

Kejadian distokia disebabkan oleh dua penyebab yaitu: (a) Lebih sering ditemukan pada hewan yang dikandangkan terus menerus dan (b) Tidak diberi kesempatan untuk bergerak terutama pada waktu bunting. Kebebasan bergerak dari ternak ini akan mempertinggi kekuatan tubuh, daya tahan tubuh dan akan menghasilkan kontraksi perejanan yang lebih kuat, tidak mudah letih, partus akan berlangsung cepat (Toelihere 1985). Persentase kejadian gangguan reproduksi berdasarkan bobot pedet lahir ditampilkan pada Gambar 2.

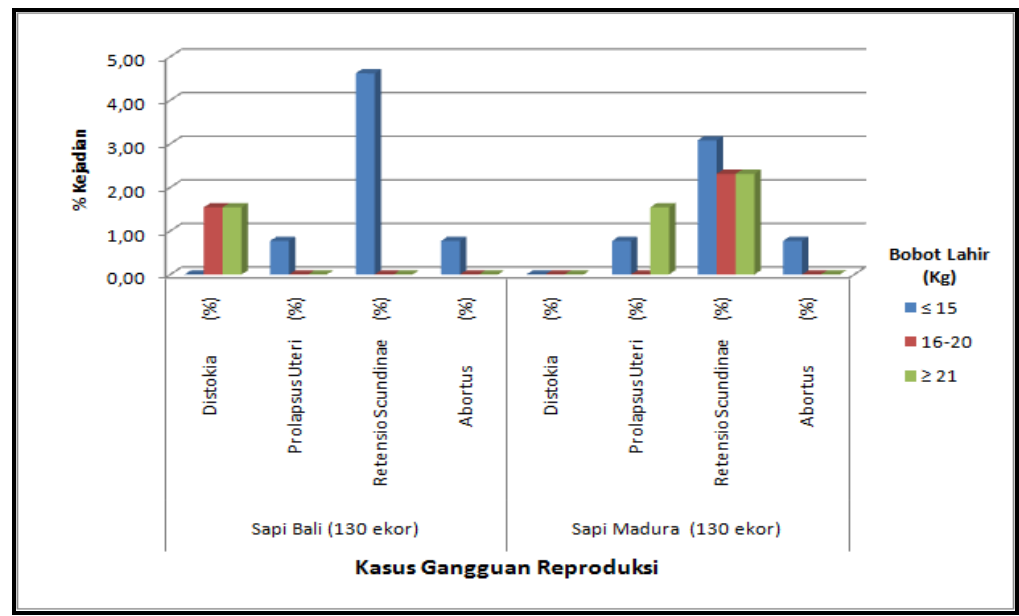

Gambar 2. Persentase kejadian gangguan reproduksi berdasarkan bobot lahir pedet sapi Bali dan Madura

Tampilan persentase kejadian gangguan reproduksi berdasarkan bobot lahir pedet pada Gambar 1. menunjukkan bahwa pedet sapi Bali yang lahir dengan bobot di atas $16 \mathrm{~kg}$ memiliki peluang menjadi penyebab terjadinya distokia, sedangkan kejadian gangguan reproduksi prolapsus uteri, retensio scundinae dan abortus pada pedet sapi Madura memiliki peluang terjadi pada semua katagori bobot lahir. Menurut Toelihere (1985) bahwa sebab dasar distokia antara lain karena faktor herediter, nutrisi dan manajemen, adanya penyakit menular dan traumatik. Sedangkan sebab langsung berasal dari fetal atau maternal. Lebih lanjut Toelihere (2006) menyatakan bahwa distokia terjadi karena pelvis yang kecil dan tidak berkembang, saluran reproduksi yang kerdil, resistensi rendah terhadap penyakit serta kekurangan tenaga untuk mengeluarkan foetus dalam keadaan normal.

Jakson (2007) menyatakan bahwa beberapa hal yang harus dilakukan untuk pencegahan terjadi kembalinya distokia antara lain: (a) Pengaturan manajemen pakan yang baik sebelum dan saat kebuntingan; (b) Sapi tidak di-IB dengan semen ras yang ukuran badan lebih besar dari indukan; (c) Pencegahan penyakit reproduksi sapi seperti Salmonellosis dan Brucellosis; (d) Exercise yang cukup pada sapi bunting; (e) Pengawasan kebuntingan sejak dini; (f) Pemeriksaan organ reproduksi secara teratur.

Pemenuhan kebutuhan nutrisi merupakan salah satu faktor yang sangat penting dalam memicu timbulnya kejadian gangguan reproduksi sapi potong terutama di daerah tropis. Nutrisi dan cadangan energi tubuh dibutuhkan dalam proses metabolisme, sintesis hormon reproduksi, pertumbuhan, laktasi dan aktivitas reproduksi. Menurut Budiyanto et al. (2016) bahwa kekurangan nutrisi mengakibatkan penurunan fungsi ovarium atau hipofungsi ovarium dan dalam jangka waktu lama dapat menjadi atropi ovarium yang bersifat irreversible serta panjangnya durasi anestrus postpartum >60-90 hari. 
Kondisi di lapangan dan beberapa hasil penelitian telah menunjukkan bahwa faktor nutrisi merupakan faktor utama dalam mempengaruhi kinerja reproduksi dibandingkan dengan faktor lainnya. Jadi, nutrisi yang cukup dapat mendorong proses biologis untuk mencapai potensi genetiknya, mengurangi pengaruh negatif dari lingkungan yang tidak nyaman dan meminimalkan pengaruh-pengaruh dari teknik manajemen yang kurang baik. Nutrisi yang kurang baik tidak hanya akan mengurangi performa di bawah potensi genetiknya, tetapi juga memperbesar pengaruh negatif dari lingkungan. Kekurangan pakan khususnya untuk daerah tropis yang panas termasuk di Indonesia, merupakan salah satu penyebab penurunan efisiensi reproduksi karena selalu diikuti oleh adanya gangguan reproduksi yang menyebabkan timbulnya kemajiran pada ternak betina (Budiyanto 2012).

\section{KESIMPULAN}

Tingkat kejadian tertinggi pada gangguan reproduksi berdasarkan umur, bobot induk waktu melahirkan dan bobot lahir pada sapi Bali dan Madura adalah kasus retensio scundinae. Guna mencegah timbulnya kejadian gangguan reproduksi dalam usaha peternakan sapi yaitu dalam sistem pemeliharaan induk sapi harus memperhatikan pakan, kandang, sanitasi dan kesehatan serta bangsa sapi dikarenakan kemampuan reproduksi masing-masing bangsa sapi berbeda.

\section{UCAPAN TERIMA KASIH}

Penulis menyampaikan terima kasih kepada Dr. Ir. Dicky Pamungkas selaku Kepala Loka Penelitian Sapi potong yang telah memberikan kesempatan penulis untuk dapat melakukan kegiatan penelitian dan Drs. Lukman Affandhy S yang telah memberikan saran dan masukkan serta Tim Teknisi Reproduksi Pemuliaan Ternak (Moch. Chanafi, Dadang Karnadi dan Wahyuni Indah Wulansari) yang telah membantu malakukan PKB dan recording sehingga penelitian dapat berjalan dengan baik.

\section{DAFTAR PUSTAKA}

Affandhy L, Pratiwi WC, Ratnawati D. 2007. Penanganan gangguan reproduksi pada sapi potong. Bogor (Indonesia): Pusat Penelitian dan Pengembangan Peternakan.. hlm. 17-21.

Anderson P. 2012. Cow/Calf Management: Minimizing calving difficulty in beef cattle. University of Minnesota Extension. Americans with Disabilities Act. p. 1-10.

Anggorodi R. 1994. Ilmu Makanan Ternak Umum. Jakarta (Indonesia): PT Gramedia.

Bugiwati SRA. 2007. Body dimension growth of calf bull in Bone and Baru District, South Sulawesi. J Sains Teknol. 7:103-108.

Budiyanto A. 2012. Peningkatan tingkat kebuntingan dan kelahiran sapi di Indonesia dan masalahmasalah yang terkait. Makalah disampaikan pada Seminar Updating Penyakit Gangguan Reproduksi dan Penanganannya pada Ruminansia Besar, 8 Maret 2012. PDHI Cabang DIY.

Budiyanto A, Tophianong TC, Triguntoro, Dewi HK. 2016. Gangguan reproduksi sapi Bali pada pola pemeliharaan semi intensif di daerah sistem integrasi sapi-kelapa sawit. Acta Vet Indones. 4:14-18.

Hardjopranjoto S. 1995. Ilmu kemajiran pada ternak. Surabaya (Indonesia): Airlangga Universitas Press.

Hayati, Choliq. 2009. Ilmu reproduksi hewan. Jakarta (Indonesia): PT Mutiara Sumber Widya. 
Jackson PG. 2007. Handbook obstetrik veteriner. Edisi ke-2. Junaidi A, penerjemah. Yogyakarta (Indonesia): Gadjah Mada University Press.

Noor RR. 2010. Genetika ternak. Edisi ke-6. Jakarta (Indonesia): Penebar Swadaya.

Nijman IJ, Otsen M, Verkaar ELC, de Ruijter C, Hanekamp E, Ochieng JY, Shamshad E, Rege JEO, Hanotte O, Bavergen MW, Susilawati T, Lenstra JA. 2003. Hybridization of Banteng (Bos javanicus) and Zebu (Bos Indicus) Revealed by Mitocondrial DNA, Satelite DNA, AFLP and Microsatellite. Hered J. 90:10-16.

Peters AR, Ball PJH. 2007. Reproduction in cattle. Thrid edition. Oxford (UK): Blackwell Publishing. p. 166-170.

Phocas F, Laloe D. 2003. Evaluation models and genetic parameters for calving difficulty in beef cattle. J Anim Sci. 81:933-938.

Roberts SJ. 2012. Veterinary obstetrics and genital diseases. Paperback. White Fish (USA): Literary Licensing, LLC. 566 p.

Salisbury GW, van Demark NL, Lodge JR. 1993. Fisiologi reproduksi daninseminasi buatan pada sapi. Djanuar, Penerjemah. Yogyakarta (Indonesia): Universitas Gadjah Mada.

Tillman, Allen D, Hartadi H, Reksohadiprodjo S, Prawirokusumo S, Lebdosoekojo S. 1998. Ilmu Makanan Ternak Dasar, Cetakan VI. Yogyakarta (Indonesia): Gadjah Mada University Press.

Toelihere M.R. 1985. Fisiologi reproduksi pada ternak. Bandung (Indonesia): Angkasa.

Toelihere M.R. 2006. Ilmu kebidanan pada ternak sapi dan kerbau. Jakarta (Indonesia): Universitas Indonesia Press.

\section{DISKUSI}

\section{Pertanyaan}

1. Kenapa kejadian gangguan reproduksi umumnya terjadi pada umur $>5$ tahun? Selain iitu, bobot Badan <250 kg berpotensi terjadi gangguan reproduksi lebih besar juga, berikan alasannya? Adakah kaitan antara kandang dengan kejadian gangguan reproduksi?

2. Bagaimana penanganan prolapsus? Adakah kemungkinan terjadinya kebuntingan?

\section{Jawaban}

1. Kejadian gangguan reproduksi umumnya pada sapi umur $>5$ tahun berkaitan dengan umur dan asupan makan. Untuk sapi induk dengan bobot badan $<250 \mathrm{~kg}$ mengalami kesulitan melahirkan karena kehabisan tenaga akibat suplai asupan pakan untuk pedet juga.

2. Sulit penanganan dan kemungkinan terjadinya kebuntingan, sebaiknya dijual. 